\title{
Nuclei DNA Damage Due to Extreme High-Temperature Exposure during Forensic Identification Examination
}

\author{
Ahmad Yudianto, ${ }^{1,2,3}$ Masniari Novita, ${ }^{4}$ Ariyanto Wibowo, ${ }^{1}$ Fery Setiawan ${ }^{2}$ \\ ${ }^{1}$ Department of Forensic and Medicolegal Medicine Faculty of Medicine Universitas Airlangga/Dr. Soetomo \\ General Hospital Surabaya, Indonesia, ${ }^{2}$ Forensic Science Master Program, Postgraduate School \\ Universitas Airlangga, Surabaya, Indonesia, ${ }^{3}$ Human Genetics Study Group, Institute of Tropical Diseases \\ Universitas Airlangga, Surabaya, Indonesia, ${ }^{4}$ Forensic Odontology, Faculty of Dentistry \\ Jember University, Indonesia
}

\begin{abstract}
Accurate personal identification is important in investigations because an error in the identification process may bring fatal consequences during trial. The most common identification process is the Deoxyribonucleic acid [DNA] analysis. Degraded DNA sample due to extremely high-temperature exposure may limit DNA analysis. This study aimed to analyze DNA damage patterns caused by an extremely high temperature using short tandem repeat (STR) CODIS marker. This study was conducted at the Forensic and Medicolegal Department, Laboratorium Balai Besar Kesehatan Surabaya, Ministry of Health of the Republic of Indonesia, Human Genetic Study Group of Universitas Airlangga, and Faculty of Science and Technology of Universitas Brawijaya Malang from July until October 2009. Results of PCR visualization using STR CODIS for costae demonstrated that the THO1 detection $(+)$ in $1,250^{\circ} \mathrm{C}-$ 40': $25 \%$ and the TPOX detection $(+)$ in $1,000^{\circ} \mathrm{C}-30^{\prime}: 50 \%$ whereas the results from molar teeth showed that the THOI locus detection (+) in $1,250^{\circ} \mathrm{C}-30^{\prime}: 25 \%$ and TPOX in $1,000^{\circ} \mathrm{C}-40^{\prime}$ : $50 \%$. Results for PCR visualization using mini-STR CODIS for the costae presented that the mini-THOI in 1,250 ${ }^{\circ} \mathrm{C}-20^{\prime}: 50 \%(+)$ while for the molar tooth the mini-THOI in $1,250^{\circ} \mathrm{C}-30^{\prime}$ : $25 \%(+)$ and mini-TPOX in 1,000 ${ }^{\circ} \mathrm{C}-40^{\prime}$ : $50 \%(+)$. All loci were detected on costae and second molar teeth samples of the control group. Thus, extreme high-temperature exposure significantly decreased the DNA level of second costae and second molar tooth. Sequence patterns of STR loci successfully detected were TPOX, THO1, and CSF1PO.
\end{abstract}

Keywords: Costae, DNA level, extreme high temperature, molar tooth, short tandem repeat, combined DNA index system

\section{Kerusakan DNA Inti Karena Paparan Suhu Tinggi Selama Proses Identifikasi Forensik}

\begin{abstract}
Abstrak
Identifikasi melalui DNA secara tepat penting dalam penyelidikan karena kesalahan akan berakibat fatal selama proses persidangan. Salah satu keterbatasan adalah DNA yang terdegradasi karena paparan suhu yang sangat tinggi. Penelitian ini bertujuan menganalisis pola kerusakan DNA akibat suhu sangat tinggi menggunakan penanda CODIS short tandem repeat (STR). Penelitian dilakukan di Instalasi Kedokteran Forensik, Laboratorium Kemenkes, Human Genetic Study Group, dan Universitas Brawijaya Malang pada periode Juli sampai Oktober 2009. Visualisasi PCR menggunakan STR CODIS untuk costae adalah sebagai berikut: deteksi THO1 (+) pada $1250^{\circ} \mathrm{C}-$ 40': 25\%, deteksi TPOX (+) pada $1000^{\circ} \mathrm{C}-30^{\prime}: 50 \%$, sedangkan hasil dari gigi molar adalah sebagai berikut: THOI locus detection (+) di $1250^{\circ} \mathrm{C}-30^{\prime}$ : $25 \%$ dan TPOX di $1000^{\circ} \mathrm{C}-40^{\prime}: 50 \%$. Hasil visualisasi PCR menggunakan miniSTR CODIS untuk costae adalah sebagai berikut: mini-THOI pada $1250^{\circ} \mathrm{C}-20^{\prime}$ : $50 \%(+)$ dan untuk gigi molar: miniTHOI pada $1250^{\circ} \mathrm{C}-30^{\prime}: 25 \%$ (+) dan mini-TPOX di $1000^{\circ} \mathrm{C}-40^{\prime}$ : $50 \%$ (+). Semua lokus terdeteksi pada kelompok kontrol pada sampel costae dan gigi molar kedua. Simpulan, paparan suhu tinggi yang ekstrim secara signifikan menurunkan tingkat DNA kosta dan gigi molar kedua.
\end{abstract}

Kata kunci: Costae, gigi molar, suhu sangat tinggi, short tandem repeat, combined DNA index system, tingkat DNA

Corresponding Author: Ahmad Yudianto, Department of Forensic and Medicolegal, Faculty of Medicine Airlangga University, Surabaya, Indonesia. Jalan Prof. Dr. Moestopo No. 47, Surabaya 60132, Indonesia. Email: yudi4n6sby@yahoo.co.id 


\section{Introduction}

Forensic experts play animportant role in forensic science, specifically during the identification of mass disaster victims. Identification through DNA analysis is an accurate and stable diagnostic tool. A person's genetic information has similarities throughout his/her body cells and remains unchanged even after the person dies. During its development, the DNA analysis method has brought new limitations for its use. One of its limitations that might cause a serious problem to forensic DNA experts or other DNA experts is degraded DNA. ${ }^{1-3}$

Muscle tissue is an organ with abundant cell contents, where DNA can be found in its nucleus. Human muscle tissue is estimated to contribute to half of the human's weight and consists of 600 types of tissue. Among the most commonly used or most recommended types of muscle tissue for DNA analysis are the psoas and masseter muscle. The psoas muscle is located at the bottom part of the posterior abdominal wall, behind the diaphragm and corresponds with quadratus lumborum muscle, where artery, vein, and lymph node can be found. Meanwhile, the masseter muscle is a masticating muscle with vertical fibers to help strengthening the biting/chewing movements. ${ }^{1,3}$

Decomposition of a corpse is one of the challenges when applying the DNA analysis method. Although degraded DNA might provide great obstacles for forensic DNA experts, there are already some research and studies done to be able to do DNA analysis in certain conditions. Currently, the correlation between decomposition and fragmented DNA during forensic identification is still unclear. ${ }^{4,5,6,7}$

In DNA analysis, the unit for repetition length of less than $1 \mathrm{~kb}$ (kilobase pair) is called short tandem repeat (STR). STR is popular because it has a short allele length (less than $1 \mathrm{~kb}$ ), making it easier to amplify through PCR and analyze degraded samples. FBI recommends 13 STRCODIS loci for identification. Several studies have shown that 3 STR loci [CSF1P0, TH01, TPOX] have a high discriminant power for the Asian population. ${ }^{1,3}$ This study is aimed to investigate nuclei DNA damages after an exposure to high temperatures using the STR-CODIS technique in forensic identification.

\section{Methods}

This was a laboratory experimental randomized post-test only control group study to analyze damages in DNA retrieved from costae and tooth DNA samples due to extremely a hightemperature exposure through STR CODIS loci [CSF1P0, TPOX, TH01, miniCSF1P0, miniTH01, miniTPOX].

The samples of this study were obtained from the second costae and molar tooth DNA of corpses. The second costae and the second molar tooth were chosen because they contained more cells than the other body parts. All corpses included were bodies that were still unidentified after 48 hours, as regulated in article 133(3) of the Indonesian Criminal Procedure Code (KUHAP) and Government Regulation (PP) no. 81/1981. There were 24-second costae and 24-second molar teeth included as the samples in this study. Each of them was replicated 6 times so that the number of $n$ (replication) was 6 for molar teeth and 6 for costae. Whole costae and molar teeth were removed from the corpses without being cut, and then each sample was wrapped with aluminum foil and heated using the Naberthem muffle furnace up to $1,400^{\circ} \mathrm{C}$. The samples were then grouped according to the treatment into the exposure to $1,000^{\circ} \mathrm{C}$ for 20 , 30 , and 40 minutes; exposure to $1,250^{\circ} \mathrm{C}$ for 20 , 30 , and 40 minutes; and exposure to $1,400^{\circ} \mathrm{C}$ for 20 minutes, 30 minutes, 40 minutes. A separate group without any exposure to heat was used as the control group. $1,8,9$

DNA samples (from the bone and molar tooth samples) that had been exposed to extremely high temperatures were extracted and isolated. These samples were collected from a corpse during the autopsied process after $2 \times 24$ hours in the forensic laboratory. They did not have any address so that they were usually referred to as "Tempat Tinggal Tidak Tetap" (T4) or residency unknown. This study was approved by Dr. Soetomo Ethics Committee under the ethical clearance number 48/panke.KKE/VI/2009 and was performed at the Institute of Tropical Disease Human Genetics, Biology Molecular Laboratorium, Faculty of Science and Technology, Universitas Brawijaya Malang. Materials for DNA extraction and isolation were DNAzol Reagent, 100\% Ethanol and 70\% Ethanol solution. The DNA samples were amplified by Polymerase Chain Reaction [PCR] using the PCR Mix [dNTP (ATP, CTP, TTP GTP), MgCl2, Taq Polimerase], nuclease-free water, as well as primers and mini primers of Short Tandem Repeats [STR] Combined DNA Index System [CODIS] loci that consisted of CSF1PO [Gen Bank Accession X14720]: 5'-AACCTGAGTCTGCCAAGGACTAGC- 
3'\&5' TTCCACACACCACTGGCCATC TTC-3'; TH01 [Gen Bank Accession D00269]:5'C TGGG CA C G T GA GG G CA G C G T C T- 3' \& 5' TGCCGGAAGTCCATCCTCACAGTC-3'; and TPOX [Gen Bank Accession M68651]: 5'-ACTGGCACAGAACAGGCATCTAGG-3'\&5' GGAGGAACTGGGAACCACACAGGT-3'.

In addition to primers, some mini primers were also used, including the mini CSF1P05'-ACAGTAACTGCCTTCATAGATAG 3'\&5'-GTGTCAGACCCTGTTCTAAGTA-3'; mini TH01 5'-CCTGTTCCTCCCTTATTTCCC-3'\&5'GGGAACACAGACTCCATGGTG-3'; and mini TPOX 5'-CTTAGGGAACCCTCACTGAATG-3'\&5'GTCCTTGTCAGCGTTTATTTGC-3' (22).

PCR amplification cycles for CSF1PO, THOI, TPOX locus were performed as followed: initial denaturation at $96^{\circ} \mathrm{C}$ for 2 minutes, followed by 10 cycles of subsequent denaturation at $94^{\circ} \mathrm{C}$ for 1 minute, annealing at $64^{\circ} \mathrm{C}$ for 1 minute, amd extension at $70^{\circ} \mathrm{C}$ for 1 minute 30 seconds and 30 cycles of denaturation at $90^{\circ} \mathrm{C}$ for 1 minute, annealing at $64^{\circ} \mathrm{C}$ for 1 minute, extension at $70^{\circ} \mathrm{C}$ for 1 minute 30 seconds. Meanwhile, the PCR amplification cycles for miniCSF1PO, miniTHOI, miniTPOX locus consisted of an initial denaturation at $96^{\circ} \mathrm{C}$ for 10 minutes, followed by 30 cycles of denaturation at $94^{\circ} \mathrm{C}$ for 1 minute, annealing at $55^{\circ} \mathrm{C}$ for 1 minute, and extension at $72^{\circ} \mathrm{C}$ for 1 minute and then the final extension at $65^{\circ} \mathrm{C}$ for 45 minutes. PCR amplification products were visualized using the Polyacrylamide agarose gel electrophorese [PAGE] and silver nitrate staining. ${ }^{1}$

Results were then analyzed statistically using both parametric and non-parametric statistics depending on the normality of the data. The parametric statistics consisted of an independent sample t-test while the non-parametric statistics consisted of the chi-square test, Pearson chisquare, and fisher's exact test.

\section{Results}

The experiment in this study was started with exposing the second costae and molar tooth samples to an extremely high-temperature of $1,000^{\circ} \mathrm{C}$ for 20 minutes, 30 minutes, and 40 minutes; $1,250^{\circ} \mathrm{C}$ for 20 minutes, 30 minutes, and 40 minutes; and $1,400^{\circ} \mathrm{C}$ for 20 minutes, 30 minutes, and 40 minutes. The measurement of DNA contents and purity from the extracted samples were conducted using the UV-Visible Spectrophotometer. The results of DNA level measurement is presented in the following table: Table 1 lists the mean DNA level $(\mu \mathrm{g} / \mathrm{mL})$ from all groups of costae and second molar teeth samples. A chart representation of these data is given in Figure 1.

Figure 1 demonstrates a significant decrease in the DNA level from the second costae and molar tooth due to extremely high-temperature exposure. The increase in temperature was inversely proportional to the DNA level of the samples. Duration of exposure also affected the DNA level of the samples. It was also inversely proportional to the DNA level of the samples. The t-test analysis revealed a significant difference $(p<0.05)$ in decreased DNA level due to extremely high-temperature exposure, showing that extreme high-temperature exposure affected DNA level measurement. The UV spectrophotometry revealed a significant

Table 1 DNA Mean Level of Samples ${ }^{1}$

\begin{tabular}{lcc}
\hline \multirow{2}{*}{ Exposure } & \multicolumn{2}{c}{ DNA Level $(\mu \mathrm{g} / \mathrm{mL})$} \\
\cline { 2 - 3 } & Costae & Second Molar Tooth \\
\hline Without exposure & $275.50 \pm 10.35$ & $220.25 \pm 10.25$ \\
$1000^{\circ} \mathrm{C}-20$ minutes & $68.73 \pm 05.98$ & $78.75 \pm 07.25$ \\
$1000^{\circ} \mathrm{C}-30$ minutes & $60.50 \pm 13.43$ & $63.07 \pm 09.25$ \\
$1000^{\circ} \mathrm{C}-40$ minutes & $57.34 \pm 01.33$ & $60.98 \pm 11.25$ \\
$1250^{\circ} \mathrm{C}-20$ minutes & $37.84 \pm 05.89$ & $47.25 \pm 13.85$ \\
$1250^{\circ} \mathrm{C}-30$ minutes & $30.78 \pm 10.86$ & $29.23 \pm 09.25$ \\
$1250^{\circ} \mathrm{C}-40$ minutes & $10.73 \pm 11.35$ & $10.59 \pm 04.25$ \\
$1400^{\circ} \mathrm{C}-20$ minutes & $25.73 \pm 11.50$ & $15.56 \pm 10.85$ \\
$1400^{\circ} \mathrm{C}-30$ minutes & $10.76 \pm 1 ., 87$ & $16.36 \pm 10.76$ \\
$1400^{\circ} \mathrm{C}-40$ minutes & $05.55 \pm 10.65$ & $05.17 \pm 10.25$ \\
\hline
\end{tabular}




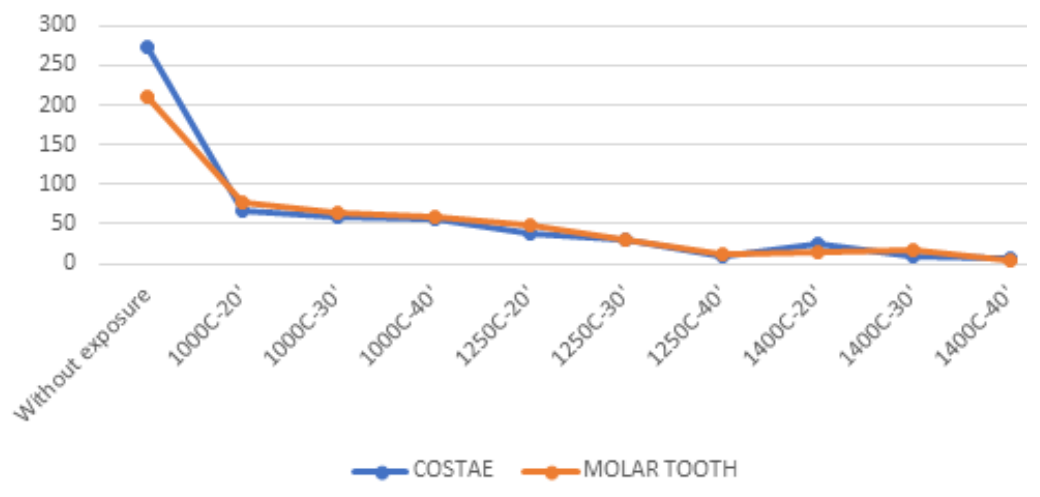

Figure 1 Mean DNA Level of Samples ${ }^{1}$

decrease in DNA samples obtained from costae and molar tooth..$^{8,9}$

Figure 2 shows two variables of the PCR visualization results: temperature and time. Temperatures used as treatment in this study were $1,000^{\circ} \mathrm{C}, 1,250^{\circ} \mathrm{C}$ and $1,400^{\circ} \mathrm{C}$ while the durations of treatment were 20 minutes, 30 minutes, and 40 minutes.

Table 2 explained the detection of all loci from primer CSF1PO, THO1, TPOX from costae, and molar tooth samples in the control group and treatment groups. The numbers of $100,75,50$, 25 , and 0 reflect the percentage of locus primer. The + and - signs indicate whether a specified locus was detected or not. For example, all locus primers of CSF1PO, TH01, and TPOX from costae and the molar tooth in the control group were detected as indicated the number 100 in the column (+) and 0 in the column (-). Meanwhile, only $75 \%$ loci of TH01 from costae samples after an exposure to $1,000^{\circ} \mathrm{C}$ for $20^{\prime}$ exposure were still detected while the remaining $25 \%$ were not detected.

Table 3 lists the results of detection of all loci for the mini primer of CSF1PO, TH01, TPOX from the costae and molar tooth in the control group and treatment groups. The numbers $100,75,50$, 25 , and 0 reflect the percentage of locus mini

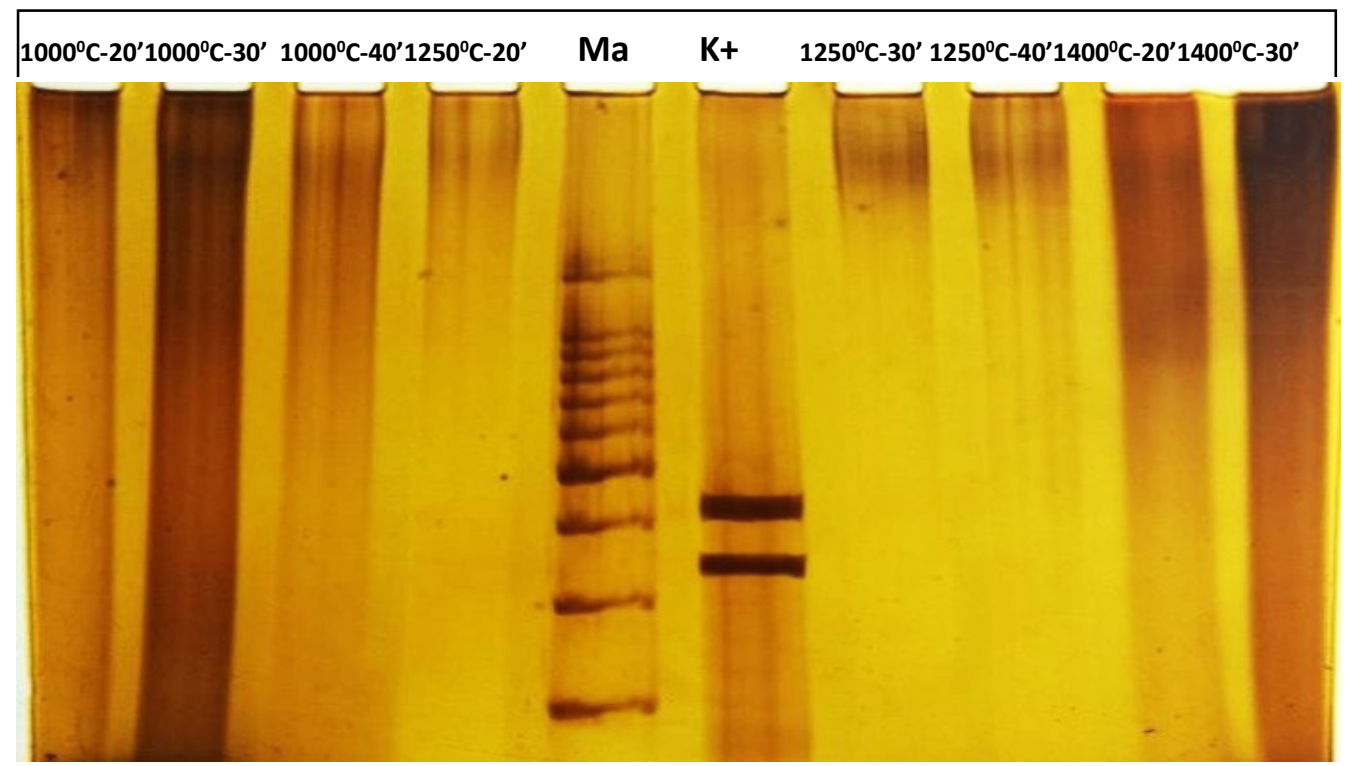

Figure 2 PCR Visualization Result of STR CODIS Locus CSF1PO [321bp-357bp], Ma [marker 100bp] in Molar Tooth Sample 
Table 2 Results of Standard STR CODIS Loci [CSF1PO, TPOX, TH01] Detection

\begin{tabular}{|c|c|c|c|c|c|c|c|c|c|c|c|c|}
\hline \multirow{3}{*}{ Exposure } & \multicolumn{6}{|c|}{ Costae [\%] } & \multicolumn{6}{|c|}{ Molar Tooth[\%] } \\
\hline & \multicolumn{2}{|c|}{ CSF1PO } & \multicolumn{2}{|c|}{ THOI } & \multicolumn{2}{|c|}{ TPOX } & \multicolumn{2}{|c|}{ CSF1PO } & \multicolumn{2}{|c|}{ THOI } & \multicolumn{2}{|c|}{ TPOX } \\
\hline & + & - & + & - & + & - & + & - & + & - & + & - \\
\hline Without Exposure & 100 & 0 & 100 & 0 & 100 & 0 & 100 & 0 & 100 & 0 & 100 & 0 \\
\hline \multicolumn{13}{|l|}{$1000^{\circ} \mathrm{C}$} \\
\hline $20^{\prime}$ & 0 & 100 & 75 & 25 & 75 & 25 & 0 & 100 & 50 & 50 & 25 & 75 \\
\hline $30^{\prime}$ & 0 & 100 & 25 & 75 & 50 & 50 & 0 & 100 & 50 & 50 & 25 & 75 \\
\hline $40^{\prime}$ & 0 & 100 & 0 & 100 & 0 & 100 & 0 & 100 & 25 & 75 & 50 & 50 \\
\hline \multicolumn{13}{|l|}{$1250^{\circ} \mathrm{C}$} \\
\hline $20^{\prime}$ & 0 & 100 & 50 & 50 & 0 & 100 & 0 & 100 & 50 & 50 & 0 & 100 \\
\hline $30^{\prime}$ & 0 & 100 & 0 & 100 & 0 & 100 & 0 & 100 & 25 & 75 & 0 & 100 \\
\hline $40^{\prime}$ & 0 & 100 & 25 & 75 & 0 & 100 & 0 & 100 & 0 & 100 & 0 & 100 \\
\hline \multicolumn{13}{|l|}{$1400^{\circ} \mathrm{C}$} \\
\hline $20^{\prime}$ & 0 & 100 & 0 & 100 & 0 & 100 & 0 & 100 & 0 & 100 & 0 & 100 \\
\hline $30^{\prime}$ & 0 & 100 & 0 & 100 & 0 & 100 & 0 & 100 & 0 & 100 & 0 & 100 \\
\hline $40^{\prime}$ & 0 & 100 & 0 & 100 & 0 & 100 & 0 & 100 & 0 & 100 & 0 & 100 \\
\hline
\end{tabular}

primer while the + and - signs indicate whether the loci were detected or not. For example, all locus mini primers of CSF1PO, THO1, and TPOX from costae and the molar tooth in the control group were detected as represented by number
100 in the column $(+)$ and 0 in the column $(-)$. All locus mini primers of THO1 from costae samples were not detected after an exposure to $1,000^{\circ} \mathrm{C}$ for 20 minutes as represented by 0 in column $(+)$ and 100 on column (-).

Table 3 Results of Mini-CODIS loci [CSF1PO, TPOX, TH01] Detection

\begin{tabular}{|c|c|c|c|c|c|c|c|c|c|c|c|c|}
\hline \multirow{3}{*}{ Exposure } & \multicolumn{6}{|c|}{ Costae [\%] } & \multicolumn{6}{|c|}{ Molar Tooth [\%] } \\
\hline & \multicolumn{2}{|c|}{ MiniCSF1PO } & \multicolumn{2}{|c|}{ MiniTHOI } & \multicolumn{2}{|c|}{ MiniTPOX } & \multicolumn{2}{|c|}{ MiniCSF1PO } & \multicolumn{2}{|c|}{ MiniTHOI } & \multicolumn{2}{|c|}{ MiniTPOX } \\
\hline & + & - & + & - & + & - & + & - & + & - & + & - \\
\hline Without Exposure & 100 & 0 & 100 & 0 & 100 & 0 & 100 & 0 & 100 & 0 & 100 & 0 \\
\hline \multicolumn{13}{|l|}{$1000^{\circ} \mathrm{C}$} \\
\hline $20^{\prime}$ & 0 & 100 & 0 & 100 & 0 & 100 & 0 & 100 & 0 & 100 & 0 & 100 \\
\hline $30^{\prime}$ & 0 & 100 & 0 & 100 & 0 & 100 & 0 & 100 & 0 & 100 & 0 & 100 \\
\hline $40^{\prime}$ & 0 & 100 & 0 & 100 & 0 & 100 & 0 & 100 & 0 & 100 & 50 & 50 \\
\hline \multicolumn{13}{|l|}{$1250^{\circ} \mathrm{C}$} \\
\hline $20^{\prime}$ & 0 & 100 & 50 & 50 & 0 & 100 & 0 & 100 & 0 & 100 & 0 & 100 \\
\hline $30^{\prime}$ & 0 & 100 & 0 & 100 & 0 & 100 & 0 & 100 & 25 & 75 & 0 & 100 \\
\hline $40^{\prime}$ & 0 & 100 & 0 & 100 & 0 & 100 & 0 & 100 & 0 & 100 & 0 & 100 \\
\hline \multicolumn{13}{|l|}{$1400^{\circ} \mathrm{C}$} \\
\hline $20^{\prime}$ & 0 & 100 & 0 & 100 & 0 & 100 & 0 & 100 & 0 & 100 & 0 & 100 \\
\hline $30^{\prime}$ & 0 & 100 & 0 & 100 & 0 & 100 & 0 & 100 & 0 & 100 & 0 & 100 \\
\hline $40^{\prime}$ & 0 & 100 & 0 & 100 & 0 & 100 & 0 & 100 & 0 & 100 & 0 & 100 \\
\hline
\end{tabular}




\section{Discussion}

The reduction of DNA level due to extremely high-temperature exposure is not a limitation for further examinations as the DNA level needed for Short Tandem Repeat (STR) test is only a minimum of $0.25-2 \mathrm{ng}$, as shown in Table 1. Thus, the STR test could be conducted in such low level. The DNA content factor is one of the essential aspects of amplification success in DNA analysis. A decrease of DNA level up to $1 \mathrm{ng}$ might bring a decrease to the STR's detection ability up to $95 \%{ }^{6,8,11}$

The effect of high-temperature exposure, such as those in the cremation process, is divided into 4 stages: dehydration, decomposition, inversion, and fusion. These stages are reflected through color changes that represent the ongoing chemical processes in bones and teeth due to the high temperature exposure. ${ }^{10,11}$

The DNA level correlates with the number of nucleated cells in tissues. A bone has nucleated bone cells (osteocytes) of around 20,000$45,000 / \mathrm{mm}^{3}$, whereas a tooth has nucleated tooth cells (odontoblast) of around 20,000-26,000/ $\mathrm{mm}^{3}$. Theoretically speaking, the amount of DNA contained in bone is higher than the amount in a tooth. The outer structure of bones and teeth in terms of protection also plays an important role in their resilience against external exposure.,10,11

Bone and tooth hardness depends on the amount of inorganic materials contained in the matrix while the strength depends on the organic materials, especially collagen fibers. Teeth enamel consists of $96 \%$ inorganic minerals, mainly calcium and phosphorus, and only $4 \%$ of organic matters and water. Dentin is the inner part of the tooth structure that has a harder structure compared to the bone but is softer than enamel, where $70 \%$ of dentin consists of inorganic materials (mainly calcium and phosphor) and $30 \%$ of dentin consists of organic materials and water. Furthermore, $50 \%$ of bone consists of inorganic materials. A second molar, based on its pulp size, is regarded as a taurodont (tooth with a large pulp chamber) with patterned cusps containing of boxes (the second molar has $20 \%$ more boxes), making it the strongest tooth compared to other types of the tooth. ${ }^{8,9}$

The direct effect of extremely hightemperature exposure is the loss of fluid contained in materials. In dental materials, the weight decreases from $28.6-66.7 \%$, and the decrease in bone materials is 65.1-91.8\%. Dental materials also have a higher hydroxyapatite (calcium-phosphate) content compared to bone. ${ }^{9}$
The amplification process begins with DNA template preparation through extraction and isolation process using an extraction kit (DNAzol). The PCR process uses a standard primer at STR CODIS loci [CSF1PO, TH01, TPOX]. To determine the effects of extremely hightemperature exposure and its duration to DNA level both in bone or tooth, Short Tandem Repeat (STR) examination is conducted to particular loci using the PCR method. In this study, the DNAzol extraction method was used and followed by ethanol precipitation. The advantage of ethanol precipitation is that it can separate DNA through precipitation while its disadvantage is that it can decrease the DNA level obtained through extraction. Before DNA extraction from the bones and teeth is performed, decalcification is conducted to remove calcium content. In PCR visualization of STR CODIS loci, the bands could be seen, showing that the DNA template was able to stick to the primers. ${ }^{1,11,12}$

Nucleated cells that contain DNA in bone or teeth are surrounded by a matrix containing calcium-phosphate element, which is an intercellular substance; therefore, an effort is needed to "extract" DNA through decalcification phases. The need for decalcification and nondecalcification before DNA extraction from bones or teeth is still debatable. Opinions that support decalcification before the DNA extraction process argue that calcium might affect the amplification process. DNA extraction might be conducted without a decalcification process due to considerations of practicality and effectiveness the DNA extraction process. During DNA extraction without decalcification, it is expected that the duration of DNA profiling might be shortened and the identification process might be completed quickly and precisely. ${ }^{3}$

The bone DNA extraction method concluded that the fastest time to decalcify bone before the DNA extraction process is around 4 hours. This relatively time-consuming process makes the non-decalcification method for bone DNA extraction becomes something to consider. However, inorganic materials that protect bone and dental cells might become an obstacle for DNA testing if no decalcification process is conducted. ${ }^{1,8}$

Decalcification might be done using several methods and materials, which include the use of chelating materials. The most commonly used chelating material is Ethylene Diamine Tetraacetic Acid (EDTA) in the form of iodized salt. Although it is acidic, it does not act as a mineral nor as an organic acid but rather functions to 
capture metal ions, specifically calcium ions. Because of its nature, which can only bind to calcium ions, this compound only works on the outer layer of bones and teeth (apatite crystals). The decalcification process with chelating materials is slow but does not affect other tissue elements that even the enzymes contained in it are still active even though the bones or teeth have undergone the decalcification process.

The non-decalcification process will give better results because less DNA is lost in the preparation process. EDTA needs to be used carefully because it is a PCR inhibitor. Residues or presence of residual EDTA in DNA extraction results is something to consider. This is important because the presence of residual EDTA in DNA isolate that will be used as DNA templates in the PCR process might reduce the $\mathrm{Mg}^{2+}$ concentration (as a catalyst in PCR) in an optimal PCR mix. In addition to residual EDTA, it is also necessary to be aware of $\mathrm{PO}_{4}$, which contaminates the DNA templates and is a PCR inhibitor ${ }^{1}$

Although this study reported the decrease of DNA sample level as an effect of high-temperature exposure, this reduction does not affect the DNA testing success through Short Tandem Repeat (STR). The DNA level needed for examination with STR tends to be less compared to other DNA tests; hence, the failure of DNA amplification is very slim. The Short Tandem Repeat is a popular marker of DNA repetition in forensic DNA because various loci on STR have small allele sizes (less than $1 \mathrm{~kb}$ and most are $300 \mathrm{bp}$ in sizes). This makes STR amplification using the PCR method easy despite the degraded samples. The number of repetitions in the STR marker itself varies greatly between individuals, making it very effective to be used for human identification. Strengths of STR include high discriminant power $(>0.9)$, heterozygotes $(>70 \%)$, low mutations, low 'stutter characteristics', stronger results and reproducibility, and presence in all chromosomes. ${ }^{1,6}$

The results of this study shows no difference between bone and tooth components' ability to protect nuclei and mitochondrial DNA during certain conditions, including high-temperature exposure. Bones and teeth components can protect bone and tooth DNA from damage that might cause fragmented DNA. ${ }^{1}$

Studies on STR CODIS as a whole have not been reported, with several studies are only done for some primers. The same is also true for mini STR CODIS. The result of this study represents the use of STR CODIS with TPOX,
TH01, and CSF1PO a s the sequence patterns of STR loci that were successfully detected according to their respective GC content ratio. THO1 and TPOX GC content ratios had the same relative value of 0.48 , when compared to CSF1PO where the GC content ratio is 0.33 . These loci can be successfully detected due to differences in amplification products and the presence of GC content or guanine and cytosine bonds in each locus. GC content or guanine-cytosine bonds have a high level of stability against denaturation factors than the bonds between Adenine and Thymine. ${ }^{1,3,10}$

Exposure to extreme high temperatures $\left[1,000^{\circ} \mathrm{C}-1,400^{\circ} \mathrm{C}\right]$ significantly $[p<0.05]$ reduces the DNA level of the second costae and molar tooth materials. The STR CODIS and mini-STR loci detection reveals that dental materials might provide adequate protection, where loci are still detected $(25 \%)$ regardless of high temperature $\left(1,250^{\circ} \mathrm{C}-30^{\prime}\right)$. Sequence patterns of STR loci that were successfully detected are TPOX, THO1, and CSF1PO based on their respective GC content ratio. The GC content ratios for THO1 and TPOX have the same relative value of 0.48 , compared to CSF1PO where the relative value is 0.33 . This limitation of this study is that the samples of DNA were only obtained from corpses in Surabaya.

\section{References}

1. Yudianto A. Analisis DNA tulang dan gigi pada lokus short tandem repeatscombined DNA index system (STR-CODIS), Y-Chromosome STRs \& mitochondrial DNA (mtDNA) akibat efek paparan panas suhu tinggi [dissertation] Surabaya: Universitas Airlangga; 2010. Available from: http:// repository.unair.ac.id/32039/.

2. Yudianto A. Pemeriksaan identifikasi forensik molekuler. Surabaya: Global Persada Press; 2015.

3. Yudianto A. Pemeriksaan forensik DNA tulang dan gigi : identifikasi pada DNA Lokus STR CODIS, Y-STRs dan mtDNA. Surabaya: Sintesa; 2020.

4. Butler JM. The future of forensic DNA analysis. Philos Trans R Soc Lond B Biol Sci. 2015;370(1674):20140252.

5. Karni M, Zidon D, Polak P, Zalevsky Z, Shefi O. Thermal degradation of DNA. DNA Cell Biol. 2013;32(6):298-301.

6. Sultana GNN, Sultan MZ. Mitochondrial DNA and methods for forensic identification. J 
Forensic Sci \& Criminal Inves. 2018;9(1):16.

7. Kantidze OI, Velichko AK, Luzhin AV, Razin SV. Heat stress-induced DNA damage. Acta Naturae. 2016;8(2):75-8.

8. Krishan K, Kanchan T, Garg AK. Dental evidence in forensic identification-an overview, methodology and present status. Open Dent J. 2015;9:250-6.

9. Ibrahim AN, Bhat V, Shenoy SM, Shetty VA. Quantitative evaluation of DNA from the tooth pulp exposed to varying temperatures. NUJHS. 2016;6(3):6-9.
10. Tozzo P, Scrivano S, Sanavio M, Caenazzo L. The Role of DNA degradation in the estimation of post-mortem interval: a systematic review of the current literature. Int J Mol Sci. 2020;21(10):3540.

11. Latham KE, Miller JJ. DNA recovery and analysis from skeletal material in modern forensic contexts. Forensic Sci Res. 2018; 4(1):51-9.

12. Giglia-Mari G, Zotter A, Vermeulen W. DNA damage response. Cold Spring Harb Perspect Biol. 2011;3(1):a000745. 